\title{
Heterogeneity among Whorl-forming Streptomycetes Determined by DNA Reassociation
}

\author{
By H. TOYAMA, M. OKANISHI AND H. UMEZAWA \\ Department of Antibiotics, National Institute of Health, \\ Kamiohsaki, Shinagawa-ku, Tokyo, Japan
}

(Received 23 July 1973; revised I4 September 1973)

\begin{abstract}
SUMMAR Y
DNA-DNA reassociation was studied in order to determine the genomic relatedness among 26 species of whorl-forming streptomycetes. DNA from Streptoverticillium kentuchense ISP5052, Stv. abikoense At-37 and Stv. eurocidicum At-267 which showed a low relationship with each other were selected as the reference samples. Relative reassociation values of various streptoverticillia compared with these reference DNAs ranged from 25 to $82 \%$ and most were less than $50 \%$. These results suggest that the whorl-forming streptomycetes are a mixture of heterogeneous species when considered at the genomic level. The results also suggest close relationships between Stv. flavopersicum ISP5053 and Stv. netropsis ISP5259 and also among Stv. ehimense ISP5253, Stv. luteoverticillatum ISP5038 and Streptomyces reticuli var. latumcidicus At-79. The close relationships within the latter three species were confirmed by their DNA reassociation with Stv. ehimense reference DNA and by thermal dissociation profiles of the hybrid DNAs on membrane filters. From data obtained, the suitability of several diagnostic features as taxonomic criteria was discussed.
\end{abstract}

\section{INTRODUCTION}

The relative reassociation value given by DNA-DNA reassociation methods expresses the relatedness of the overall genome between micro-organisms. We have already reported an improved DNA-DNA reassociation method which is highly specific in the reassociation reaction between DNA fragments and which gives reproducible results (Okanishi \& Gregory, I970). By means of this method, the traditional taxonomic criteria of Streptomyces griseus and related species were evaluated, based on a genomic relatedness (Okanishi, Akagawa \& Umezawa, 1972).

Classification systems and diagnostic keys for the whorl-forming streptomycetes have been published by Pridham, Hesseltine \& Benedict (1958), Shinobu (1965), Hütter (I967) and Locci, Baldacci \& Baldan (1969). The generic names Streptoverticillium and Verticillomyces have been proposed for these whorl-forming streptomycetes by Baldacci (1958) and Shinobu (1965) respectively. It is generally understood that these streptomycetes have the following characteristic features: the aerial mycelium branching is whorled; spore surface smooth; aerial mycelium colour in most of the species belongs to the yellow or red sections; carbohydrate utilization spectrum is very narrow; and the dibasic amino acid in the peptidoglycan wall is LL-diaminopimelic acid. From these common features, it was expected that the genome of species in this genus would also be closely related. Accordingly, an attempt was made to determine the DNA homologies among streptoverticillia, by using a membrane-filter technique established previously (Okanishi \& Gregory, 1970). 
Table I. Organisms used and their sources, except for species identified by their ISP number

Organism

Streptoverticillium abikoense At-37

Stv. eurocidicum At-267

Streptomyces alboverticillus At-286

S. reticuli At- 208

S. reticuli var. latumcidicus At-79

S. salmonicida At-155

S. thioluteus At-28

S. verticillus At-225
Source*

NIHJ Z-I-6

NIHJ 549-AI

NIHJ I IOI-A5

IID $\mathrm{H}-365$

IAM 63

NRRL B-1 472

NIHJ Z-6-23

NIHJ B8o-Z2

* NIHJ, Department of Antibiotics, National Institute of Health, Japan; IID, Institute of Medical Science, Tokyo University, Japan; IAM, Institute for Applied Microbiology, Tokyo University, Japan; NRRL, Northern Regional Research Laboratory, ARS Culture Collection and Investigations, U.S.A.

\section{METHODS}

Organisms and cultivation. Twenty-five whorl-forming species, the pseudoverticillate Actinomyces aureoverticillatus ISP5080 and a non-whorl forming species Actinomyces (Streptomyces) fulvoviridis ISP5I 20 were used. Eighteen cultures designated by ISP numbers were obtained from the collection of the International Streptomyces Project through the Institute of Fermentation, Osaka, Japan. The designations and sources of the other eight cultures are listed in Table I. Whorl formation in the 25 species was confirmed in our laboratory in advance. Nineteen of these whorl-forming species had been described and placed in Io of the I 2 series proposed by Locci et al. (1969) for the genus Streptoverticillium.

All organisms were preincubated at $28^{\circ} \mathrm{C}$ for 3 days in a minimal medium consisting of: glucose, $\mathrm{I} 2 \mathrm{~g}$; Casamino acids, I g; asparagine, $2 \mathrm{~g}$; glycine, $2 \mathrm{~g} ; \mathrm{NH}_{4} \mathrm{NO}_{3}$, I g; $\mathrm{MgSO}_{4} \cdot 7 \mathrm{H}_{2} \mathrm{O}$, $0.5 \mathrm{~g} ; \mathrm{CaCl}_{2} .2 \mathrm{H}_{2} \mathrm{O}, 0 . \mathrm{I} \mathrm{g}$; trace element solution (Okanishi \& Gregory, 1970), $2 \mathrm{ml}$; $\mathrm{K}_{2} \mathrm{HPO}_{4}, 2.5 \mathrm{~g}$; and distilled water to $\mathrm{I} 1$. The mycelium was transferred to fresh minimal medium supplemented with glycine $(0.5$ to $3 \%)$ and guanine- $8-\left[{ }^{3} \mathrm{H}\right](2 \mu \mathrm{Ci} / \mathrm{ml})$ or guanine- $8-\left[{ }^{4} \mathrm{C}\right](0 \cdot 2 \mu \mathrm{Ci} / \mathrm{ml})$, and incubated at $28{ }^{\circ} \mathrm{C}$ on a reciprocating shaker until growth reached the middle of exponential phase. The method for obtaining lysozyme-sensitive mycelium was that of Sagara et al. (I97I), who found that mycelia of Streptomyces griseoflavus incubated in the presence of glycine became sensitive to lysozyme action. Formation of mycelial pellets in shake-cultured broth was prevented by placing a spring coil of stainless steel in the medium.

Extraction and purification of DNA. Harvested mycelia were washed with a solution consisting of $0 . \mathrm{I}$ M-ethylenediaminetetraacetate and $0.15 \mathrm{M}-\mathrm{NaCl}$ (EDTA saline), $\mathrm{pH} 7 \cdot 2$. The mycelia (e.g. I $\mathrm{g}$ of wet $\mathrm{wt}$ ) suspended in $5 \mathrm{ml}$ of EDTA saline were treated with $2 \mathrm{mg}$ of lysozyme/ml (grade I, Sigma Chemical Co., St Louis, Missouri, U.S.A.) and $50 \mu \mathrm{g}$ of Lytic enzyme no. $2 / \mathrm{ml}$ (supplied by Kyowa Kakko Kogyo Co., Tokyo, Japan) at $37^{\circ} \mathrm{C}$ for I to $2 \mathrm{~h}$. To this lysate, $2 \mathrm{ml}$ of $0.2 \mathrm{M}$-tris buffered saline ( $\mathrm{pH}$ ) containing $2 \%$ $(\mathrm{w} / \mathrm{v}$ ) of sodium dodecylsulphate (tris-SDS) and $\mathrm{I} \mathrm{ml}$ of pronase (Io $\mathrm{mg} / \mathrm{ml}$ ) were added and the mixture incubated at $37^{\circ} \mathrm{C}$ for $\mathrm{I}$ to $2 \mathrm{~h}$. Then, $2 \mathrm{ml}$ of tris-SDS and $\mathrm{I} \mathrm{ml}$ of $\mathrm{I} 8 \%$ (w/v) SDS were added, and the mixture was heated at $60^{\circ} \mathrm{C}$ for $10 \mathrm{~min}$. Thereafter, DNA was extracted and purified as described previously (Okanishi \& Gregory, 1970). The guanine + cytosine content of every DNA sample was between 69 and $74 \%$ as determined by absorbance ratios described by Ulitzur (1972). 
Table 2. DNA reassociation among the whorl-forming streptomycetes

\begin{tabular}{|c|c|c|c|c|}
\hline \multirow[b]{3}{*}{ No. } & \multirow[b]{3}{*}{ Source of IM-DNA* } & \multicolumn{3}{|c|}{ Relative reassociation $(\%) \dagger$} \\
\hline & & ISP5052 & At -37 & At-26 \\
\hline & & \multicolumn{3}{|c|}{ (Reference DNA) } \\
\hline I & Stv. kentuchense ISP5052 & 100 & 34 & 一 \\
\hline 2 & Stv. flavopersicum ISP5093 & 72 & 39 & 一 \\
\hline 3 & Stv. netropsis ISP5259 & 70 & 39 & 一 \\
\hline 4 & Stv. hiroshimense ISP5037 & 57 & 48 & - \\
\hline 5 & Stv. blastmyceticum ISP 5029 & 56 & 46 & 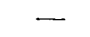 \\
\hline 6 & Stv. rubrireticuli ISP5464 & 55 & 82 & - \\
\hline 7 & A. rectiverticillatus ISP 5436 & 49 & $4 I$ & $4 \mathrm{I}$ \\
\hline 8 & S. paucisporogenes ISP 5315 & 46 & 66 & - \\
\hline 9 & Stv. hachijoense ISP5I I4 & 43 & 55 & 一 \\
\hline 10 & S. reticuli At-208 & $4 I$ & 47 & - \\
\hline II & Stv. ehimense ISP5253 & 39 & 69 & 48 \\
\hline 12 & Stv. luteoverticillatum ISP 5038 & 38 & 72 & - \\
\hline 13 & S. reticuli var. latumcidicus At-79 & 36 & 74 & 一 \\
\hline 14 & Stv. griseocarneum ISP5004 & 39 & 37 & 40 \\
\hline I5 & S. alboverticillus At-286 & 35 & 45 & - \\
\hline I 6 & Stv. abikoense At-37 & 37 & 100 & - \\
\hline 17 & A. aureoverticillatus ISP $5080 \S$ & 35 & 45 & 64 \\
\hline I 8 & S. verticillus At-225 & 35 & 45 & 54 \\
\hline 19 & Stv. roseoverticillatum ISP 5039 & 32 & 36 & 52 \\
\hline 20 & S. thioluteus At-28 & 37 & 40 & 45 \\
\hline $2 \mathrm{I}$ & A. biverticillatus ISP 5272 & 37 & 55 & - \\
\hline 22 & Stv. kishiwadense ISP5397 & 36 & 33 & 35 \\
\hline 23 & Stv. eurocidicum At-267 & 33 & 33 & 100 \\
\hline 24 & Stv. aureoversales ISP 5387 & $3 I$ & 33 & 40 \\
\hline 25 & Stv. mashuense ISP522 I & 28 & $3 I$ & 33 \\
\hline 26 & S. salmonicida At-I 55 & 28 & 25 & 37 \\
\hline 27 & A. fulvoviridis ISP52 IO & 34 & 30 & - \\
\hline
\end{tabular}

* Denatured-DNA immobilized on a membrane filter. Stv = Streptoverticillium; S = Streptomyces; $\mathrm{A}=$ Actinomyces.

$\dagger$ The relative reassociation values were calculated from the amount of the sheared-denatured DNA reassociated per unit of IM-DNA retained on a filter; the value between homologous DNAs was arbitrarily set at $100 \%$.

† These species were not included in the comprehensive study by Locci et al. (I969).

$\$$ A pseudoverticillate-forming species.

i| Non-whorl-forming Streptomyces.

$D N A-D N A$ reassociation. Reassociation of DNA was examined by the membrane-filter technique (Okanishi \& Gregory, I970), with $30 \mu \mathrm{g}$ of the sheared-denatured ${ }^{11} \mathrm{C}$-labelled DNA (SD-DNA) and $2 \mu \mathrm{g}$ of [ $\left.{ }^{3} \mathrm{H}\right] \mathrm{DNA}$ immobilized on a membrane (IM-DNA). A membrane was incubated in a vibrating incubator at $47^{\circ} \mathrm{C}$ for $24 \mathrm{~h}$ in a scintillation vial containing $0.25 \mathrm{ml}$ of $23 \times$ normal strength SSC (SSC is $0.15 \mathrm{M}-\mathrm{NaCl}$ plus $0.015 \mathrm{M}$-sodium citrate), $0.5 \mathrm{ml}$ of formamide, and $0.25 \mathrm{ml}$ of SD-DNA ( $20 \mu \mathrm{g} / \mathrm{ml})$. At the end of the incubation periods, each side of the membrane was washed with $35 \mathrm{ml}$ of double strength SSC in a conical sintered-glass filter by suction filtration. The membranes were dried under an infrared lamp for $3 \mathrm{~h}$, and then ${ }^{3} \mathrm{H}$ - and ${ }^{14} \mathrm{C}$-radioactivities were counted by a liquid scintillation counter (LS-200B, Beckman Instruments Inc., California, U.S.A.). The relative reassociation value of DNA was calculated from the amount of SD-DNA reassociated per unit of IM-DNA retained on a membrane. These reassociations were carried out with duplicate samples and the determinations were repeated twice if necessary. Results were expressed as an average of the determined values, and the standard deviation values of each determination were less than $3 \cdot 0$. 


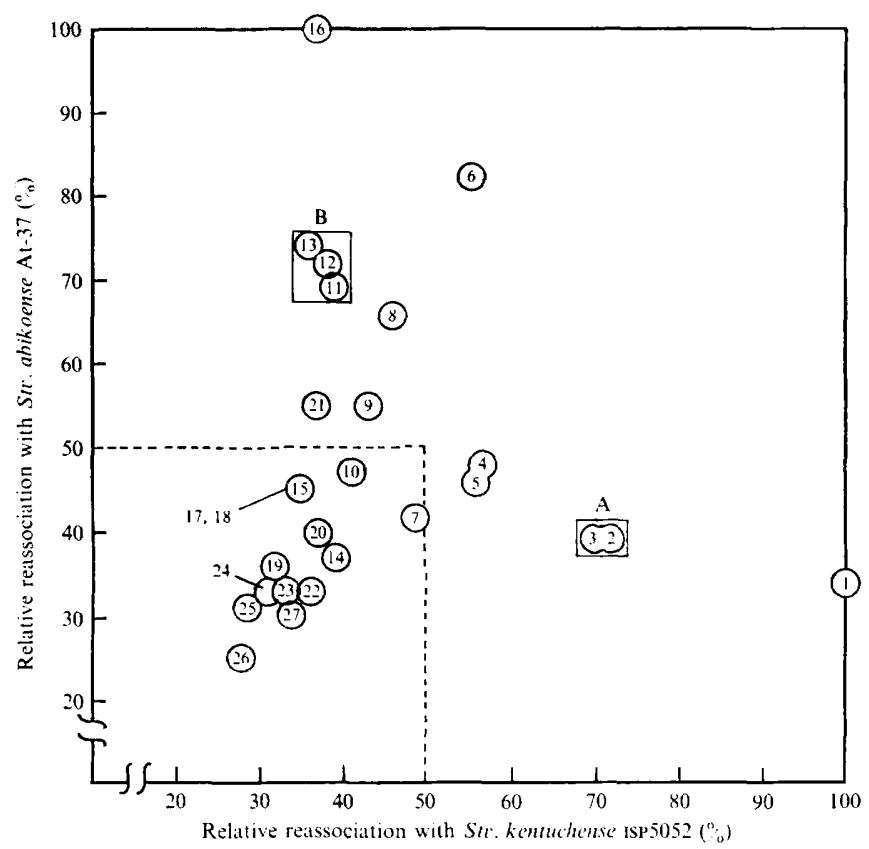

Fig. I. Interrelationships of DNAs of the whorl-forming streptomycetes. The percentage relative reassociation of each described species with Streptoverticillium kentuchense ISP5052 is plotted against the percentage relative reassociation with Stv. abikoense At-37. Each number in a circle identifies an individual species, as listed in Table 2.

Thermal dissociation of reassociated DNA. A membrane bearing reassociated DNA, washed with the double strength SSC by suction filtration, was placed in $20 \mathrm{ml}$ of $0 \cdot \mathrm{I} \times \mathrm{SSC}$ at $4{ }^{\circ} \mathrm{C}$ overnight. After rinsing briefly with $0 \cdot \mathrm{I} \times \mathrm{SSC}$, the filter was transferred from one vial to another at Io-min intervals through a series of vials containing $5 \mathrm{ml}$ of $0 \cdot \mathrm{I} \times \mathrm{SSC}$ varying in temperature from 60 to $95{ }^{\circ} \mathrm{C}$ by increments of $5{ }^{\circ} \mathrm{C}$. Carrier DNA (100 $\mu \mathrm{g}$ ) was added to each vial, and after cooling the DNA was precipitated with $5 \%(\mathrm{w} / \mathrm{v})$ trichloroacetic acid and collected on a membrane filter. The membranes were dried, and ${ }^{14} \mathrm{C}$ radioactivity was counted.

\section{RESULTS}

\section{$D N A$ reassociation among streptoverticillia}

By means of the reference DNAs obtained from Streptoverticillium kentuchense ISP5052, Stv. abikoense At-37 and Stv. eurocidicum At-267, the DNA-DNA reassociation was measured with DNAs of 26 species included in the genus Streptoverticillium (Table 2). When the DNA from Stv. kentuchense was used as a reference, the relative reassociation values obtained ranged from 28 to $72 \%$; a value of less than $50 \%$ was found in 20 species (Table 2). When the reference DNA from Stv. abikoense, showing $37 \%$ reassociation value with Stv. kentuchense, was used as a reference, the relative reassociation values obtained ranged from 25 to $82 \%$; a value of less than $50 \%$ was found in 18 species (Table 2 ). Fig. I, which was plotted with the relative reassociation values obtained, shows the interrelationships of the described species in Streptoverticillium. Thirteen species, among 26 species tested, showed a relative reassociation value of less than $50 \%$ against both reference DNAs. 
Table 3. DNA reassociation between Streptoverticillium ehimense and strains closely related to Stv. ehimense

\begin{tabular}{|c|c|c|}
\hline No.* & Source of IM-DNA $†$ & Relative reassociation $(\%)$ \\
\hline 11 & Stv. ehimense ISP 5253 & 100 \\
\hline 12 & Stv. luteoverticillatum ISP 5038 & 103 \\
\hline 13 & S. reticuli var. latumcidicus At-79 & 104 \\
\hline 8 & S. paucisporogenes ISP 53 I 5 & 76 \\
\hline 9 & Stv. hachijoense ISP5II4 & 63 \\
\hline $2 I$ & A. biverticillatus ISP 5272 & 59 \\
\hline 27 & A. fulvoviridis ISP52 $\mathrm{I} O \S$ & 40 \\
\hline
\end{tabular}

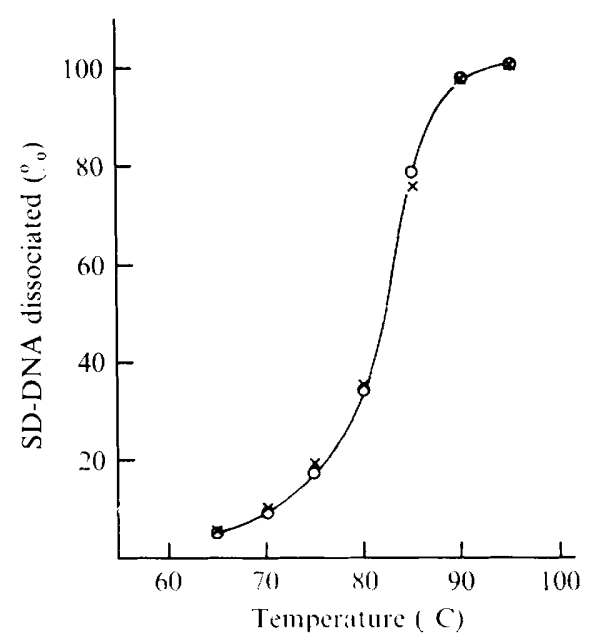

Fig. 2. Thermal-dissociation profiles of Stv, ehimense SD-DNAs reassociated with Streptoverticillium luteoverticillatum IM-DNA $(\times)$ and with the homologous Stv. ehimense IM-DNA $(O)$. The experimental procedure is described in Methods.

Using the species having less than $50 \%$ reassociation values, a further experiment was done with reference DNA from Streptoverticillium eurocidicum, located at the centre of this group (no. 23 in Fig. I). The relative reassociation values of the II species tested ranged from 33 to $64 \%$; a value of less than $50 \%$ was observed in 8 species (Table 2). The nonwhorl-forming Actinomyces (Streptomyces) fulvoviridis ISP52 Io showed relative reassociation values of 34 and $30 \%$ with Stv. kentuchense and Stv. abikoense, respectively.

\section{Relatedness among Streptoverticillium ehimense, Stv. luteoverticillatum, and Streptomyces reticuli var. latumcidicus}

Two clusters were found (Fig. I) among 13 species which showed relative reassociation values of more than $50 \%$ against either of the reference DNAs: i.e. cluster A consisting of Streptoverticillium flavopersicum ISP5093 (no. 2 in Fig. I) and Stv. netropsis ISP5259 (no. 3 in Fig. I) and cluster B consisting of Stv. ehimense ISP5253 (no. I I in Fig. I), Stv. luteoverticillatum ISP5038 (no. I 2 in Fig. I) and $S$. reticuli var. latumcidicus At-79 (no. 13 in 
Fig. I). To confirm the relationship within the cluster $B$, an additional experiment on DNA reassociation and the thermal-dissociation profile of hybrid DNAs on membrane filters was performed.

The relative reassociation value with the reference DNA from Streptoverticillium ehimense showed $103 \%$ against Stv. luteoverticillatum and $104 \%$ against S. reticuli var. latumcidicus (Table 3). The species Stv. paucisporogenes, Stv. hachijoense and Actinomyces biverticillatus, locating near cluster B in Fig. I, showed comparatively high reassociation values of 76,63 , and $59 \%$ with $S t v$. ehimense, respectively (Table 3 ). The thermal dissociation of Stv. ehimense SD-DNA reassociated with Stv. luteoverticillatum IM-DNA showed an almost identical profile to that of the SD-DNA reassociated with homologous DNA (Fig. 2).

\section{DISCUSSION}

Mycelia of the whorl-forming streptomycetes, when incubated in a medium without glycine, were hardly lysed by lysozyme. However, mycelia incubated in the presence of glycine were lysed by the lysozyme and the lysis was enhanced by adding the Lytic enzyme no. 2. In addition, DNA yield was increased by treating the lysate with pronaseSDS.

Before this study, we expected that the members of the genus Streptoverticillium which have several common taxonomic characters would be closely related with one another in the overall genome. In order to check the precise relationships among 26 described species of streptoverticillia, DNA-DNA reassociation was performed with three reference DNAs having low relative reassociation values to each other (less than $40 \%$ ). The relative reassociation values obtained in these experiments ranged from 25 to $82 \%$, and most of them were less than $50 \%$. The lowest reassociation value was approximately $30 \%$, while the lowest value obtained in the genus Streptomyces was about $40 \%$ (Okanishi et al. 1972). Unexpectedly, these results indicate that the whorl-forming streptomycetes are a heterogeneous mixture of species when considered at the genomic level.

The range of DNA reassociation values within a genus differs, depending upon the genus, e.g. a narrow range was found in Escherichia and Shigella (Brenner \& Falkow, 197I) and a wide range in Pseudomonas (Rogul, Brendle, Haapala \& Alexander, 1970; Palleroni, Ballard, Ralston \& Doudoroff, I972) and Rhizobium (Gibbins \& Gregory, 1972). We observed a wide range in Streptoverticillium in these experiments. These observations suggest that certain genera have not been properly defined or that the phenetic similarity shown by species within a genus does not accurately reflect the degree of genomic relatedness. Those species which showed a narrow range of DNA reassociation values, such as have been found in Escherichia or Shigella, can be easily understood to constitute a genus. However, those which showed a wide range of reassociation values may have to be studied more extensively.

On the other hand, the non-whorl-forming Actinomyces (Streptomyces) fulvoviridis ISP5210 gave values of 34 and $30 \%$ with Streptoverticillium kentuchense and Stv. abikoense, respectively. Taking this into account, it would be interesting to undertake further experiments to reveal relationships by DNA reassociation between species of Streptoverticillium and Streptomyces, because of their well-known phenetic similarities. This study is progressing.

The presence of two clusters in Fig. I suggests the close relatedness between Streptoverticillium flavopersicum and Stv. netropsis (cluster A in Fig. I) and also among Stv. ehimense, Stv. luteoverticillatum and Streptomyces reticuli var. latumcidicus (cluster B in 
Fig. I). The relationship among members of the latter cluster was confirmed by their DNAreassociations with Stv. ehimense reference DNA, and by thermal-dissociation profiles of the hybrid DNAs on membrane filters. Confirmations have not been done between the members of cluster A. However, except for the type of antibiotic produced, St $v$. flavopersicum and Stv. netropsis are identical when the descriptions of the International Streptomyces Project are compared, especially regarding the formation of primitive spirals in their spore chains (Shirling \& Gottlieb, 1968a,b). These identities in the overall genomes suggest that Stv. ehimense, Stv. luteoverticillatum and $S$. reticuli var. latumcidicus belong to one species, and that Stv. flavopersicum and Stv. netropsis belong to another species. The species within each cluster are identical to one another in the morphological features of spore-chain morphology and spore surface; the aerial mycelium colour, melanoid pigmentation and carbohydrate utilization pattern are also similar (Shirling \& Gottlieb, I $968 a, b$ : Sakagami et al. I958). However, the colour of the vegetative mycelium and soluble pigments, utilization of D-mannitol, and type of antibiotic produced are different among the members of cluster B (Shirling \& Gottlieb, I968a, b). These facts support the conclusions given in the previous report (Okanishi et al. 1972), except for contradictory results in respect of melanoid pigments and utilization of D-mannitol. The authors consider this discrepancy may depend on the low number of described species belonging to each cluster.

The authors are indebted to Dr T. Nara of Kyowa Hakko Kogyo Co., Tokyo, for the gift of Lytic enzyme no. 2 and to Dr Y. Okami of the Institute of Microbial Chemistry, Tokyo, for helpful discussions.

\section{REFERENCES}

BaldaCCI, E. (1958). Development in the classification of Actinomycetes. Giornale di Microbiologia 6, IO-27.

Brenner, D. J. \& Falkow, S. (I97I). Molecular relationships among members of the Enterobacteriaceae. Advances in Genetics r6, 81-1 I8.

GibBins, A. M. \& GreGORY, K. F. (1972). Relatedness among Rhizobium and Agrobacterium species determined by three methods of nucleic acid hybridization. Journal of Bacteriology III, 129-14I.

HütTER, R. (1967). Systematik der Streptomyceten. Basel: Karger.

Locci, R., Baldacci, E. \& Baldan, B. P. (1969). The genus Streptoverticillium. A taxonomic study. Giornale di Microbiologia $\mathbf{1 7}, \mathrm{I}-60$.

Okanishi, M., Akagawa, H. \& Umezawa, H. (1972). An evaluation of taxonomic criteria in streptomycetes on the basis of deoxyribonucleic acid homology. Journal of General Microbiology 72, 49-58.

OKANISHI, M. \& Gregory, K. F. (1970). Methods for the determination of deoxyribonucleic acid homologies in Streptomyces. Journal of Bacteriology 104, I086-1094.

Palleroni, N. J., Ballard, R. W., Ralston, E. \& Doudoroff, M. (1972). Deoxyribonucleic acid homologies among some Pseudomonas species. Journal of Bacteriology IIo, I-I I.

Pridham, T. G., Hesseltine, C. W. \& Benedict, R. G. (I958). A guide for the classification of Streptomyces according to selected groups. Placement of strain in morphological section. Applied Microbiology 6, 52-79.

Rogul, M., Brendle, J. J., Haapala, D. K. \& Alexander, A. D. (I970). Nucleic acid similarities among Pseudomonas pseudomallei, Pseudomonas multivorans, and Actinobacillus mallei. Journal of Bacteriology I01, $827-835$.

Sagara, Y., Fukui, K., Ota, F., Yoshida, N., Kashiyama, T. \& Fujimoto, M. (197i). Rapid formation of protoplasts of Streptomyces griseoflavus and their fine structure. Japanese Journal of Microbiology I5, 73-84.

Sakagami, Y., Yamaguchi, I., Yonehara, H., Okimoto, Y. Y., Yamanouchi, S., Takiguchi, K. \& Sakai, H. (1958). Latumcidin, a new antibiotic from Streptomyces sp. Journal of Antibiotics IrA, 6-I 3. 
SHINOBU, R. (1965). Taxonomy of the whorl-forming streptomycetaceae. Memoirs of the Osaka University of the Liberal Arts and Education B 14, 72-179.

Shirling, E. B. \& GotTliEB, D. (1968a). Cooperative description of type cultures of Streptomyces. II. Species description from first study. International Journal of Systematic Bacteriology 18, 69-189.

Shirling, E. B. \& Gottlieb, D. (I968 b). Cooperative description of type cultures of Streptomyces. III. Additional species descriptions from first and second studies. International Journal of Systematic Bacteriology 18, 279-392.

Ulitzur, S. (1972). Rapid determination of DNA base composition by ultraviolet spectroscopy. Biochimica et biophysica acta 272, I-I I. 